\title{
GEOCHEMICAL DISTRIBUTION AND MOBILITY OF HEAVY METALS IN SEDIMENTS OF URBAN STREAMS AFFECTED BY COMBINED SEWER OVERFLOWS
}

\author{
PETRA HNAŤUKOVÁ \\ Institute of Hydrodynamics AS CR, v. v. i., Pod Patankou 5, 16612 Prague 6, Czech Republic; Mailto: hnatukova@ih.cas.cz
}

This study was undertaken to assess the impact of combined sewer overflows (CSOs) on distribution and potential mobility of heavy metals in sediments of urban streams in Prague, Czech Republic. Contents of total and extractable heavy metals $(\mathrm{Cu}, \mathrm{Zn}, \mathrm{Pb}, \mathrm{Cd}, \mathrm{Cr}$ and $\mathrm{Ni})$, mineralogical phases and other sediment properties were measured in 44 surficial sediment samples. Total metal concentrations were obtained after microwave-assisted digestion whilst extractable metal contents were obtained following a sequential extraction scheme (acid soluble, reducible, oxidisable and residual fraction). The multivariate statistics of cluster analysis was used to identify specific areas of contamination and to evaluate the impact of CSOs. The observed mobility order of metals was $\mathrm{Cd}>\mathrm{Zn}>\mathrm{Ni}>\mathrm{Cu}>\mathrm{Pb}>\mathrm{Cr}$. There was a considerable increase in $\mathrm{Zn}$ mobility and increase of $\mathrm{Cu}$ associated with the oxidisable fraction in the sediments below CSO discharges. Cd was revealed as the most mobile heavy metal with percentages of extraction of approximately $40-60 \%$ in acid soluble fraction. $\mathrm{Pb}$ was mainly found in reducible fraction associated with $\mathrm{Fe} / \mathrm{Mn}$ (oxi)hydroxides, which is indicative of anthropogenic pollution. In terms of environmental significance, $\mathrm{Cd}$ and $\mathrm{Zn}$ can be particularly mobile and bioavailable under acidic conditions, because they are predominantly bound in labile fractions. However, potential changes of redox state and $\mathrm{pH}$ may remobilize the metals bound to carbonates, reducible, and/or organic matter.

KEY WORDS: Sediments, Heavy Metals, Urban Streams, Sequential Extraction, Combined Sewer Overflows.

Petra Hnatuková: GEOCHEMICKÁ DISTRIBUCE A MOBILITA TĚŽKÝCH KOVU゚ V SEDIMENTECH MĚSTSKÝCH TOKŮ OVLIVNĚNÝCH ODLEHČOVACÍMI KOMORAMI JEDNOTNÉ KANALIZACE. J. Hydrol. Hydromech., 59, 2011, 2; 27 lit., 5 obr., 2 tab.

Práce se zabývá vyhodnocením vlivu odlehčovacích komor jednotné kanalizace (OK) na distribuci a potenciální mobilitu těžkých kovů v sedimentech městských toků v Praze, České republice. Ve vzorcích 44 povrchových sedimentů byl stanoven obsah celkových i extrahovatelných těžkých kovů $(\mathrm{Cu}, \mathrm{Zn}, \mathrm{Pb}, \mathrm{Cd}, \mathrm{Cr}$ a Ni), mineralogické složení a další fyzikálně-chemické vlastnosti sedimentů. Celkový obsah kovů byl stanoven po mikrovlnném rozkladu, zatímco obsah extrahovatelných kovů byl stanoven metodou sekvenční extrakce (kyselinou extrahovatelná, redukovatelná, oxidovatelná a reziduální frakce). Pomocí mnohorozměrné shlukové analýzy byly identifikovány specifické lokality kontaminace a zhodnocen vliv $\mathrm{OK}$. Zjištěná potenciální mobilita kovů klesala $\mathrm{v}$ pořadí $\mathrm{Cd}>\mathrm{Zn}>\mathrm{Ni}>\mathrm{Cu}>\mathrm{Pb}>\mathrm{Cr}$. V sedimentech nacházejících se na profilech pod zaústěním OK byl naměřen zvýšený obsah Zn vázajícího se na nejmobilnější frakci a zvýšený obsah $\mathrm{Cu}$ vázané na oxidovatelnou frakci sedimentu. Cd bylo na všech profilech shledáno nejmobilnějším kovem s vazbou na kyselinou extrahovatelnou frakci v rozmezí cca 40 až $60 \%$. Pb bylo vázáno převážně na redukovatelnou frakci (hydratované oxidy Fe/Mn), což indikuje antropogenní zatížení tímto kovem. Z hlediska životního prostředí představují nejvýznamnější riziko převážně Cd a Zn, které se mohou za kyselých podmínek vyskytovat v mobilních a biodostupných formách, nebot' jsou nejvíce vázány na nejlabilnější složky sedimentů. Při významných změnách redoxního potenciálu a $\mathrm{pH}$ pak může dojít $\mathrm{k}$ remobilizaci kovů vázaných na karbonáty, redukovatelnou frakci $\mathrm{i}$ organickou hmotu.

KLÍČOVÁ SLOVA: sedimenty, těžké kovy, městské toky, sekvenční extrakce, odlehčovací komory jednotné kanalizace. 


\section{Introduction}

Combined sewer overflow (CSO) is a major environmental concern in cities with a combined sewer system. CSO water, composed of a mixture of urban runoff and municipal wastewater, is discharged into the natural environment during rain events, since in most European cities, there is still insufficient transport capacity in the combined or partially separated sewer systems (Even et al., 2007). In most cases, the pollution issued from CSO exceeds annual discharges from factories and sewage plants (El Samrani et al., 2004). The CSO discharge of untreated domestic sewage and stormwater into local waterways represents a large input of nutrients, organic matter and contaminants including heavy metals (Meybeck et al., 2007; Hnatukova et al., 2009). Contaminants in CSO are derived from a number of sources. Thus, materials from wet and dry atmospheric deposition, traffic and industry-related activities or released from roofs and building siding, may be flushed by rainfall and collected in the municipal sewer system. In addition, sewage and sewer-deposited material can also represent a significant contribution to CSO pollutant load (El Samrani et al., 2008). After an important rain event, suspended solids, which carry most of the trace metals transported in sewers, settle down to the bottom and accumulate in stream sediments (Estébe et al., 1998). Although most pollutants adsorbed on sediments are not readily available to aquatic organisms, variation of $\mathrm{pH}$, salinity, redox potential, content of organic chelators and hydrodynamic parameters caused by discharges of urban drainage may induce the release of metals back to the aqueous phase (Sahuquillo et al., 2003; Hiller and Šutriepka, 2008; Hnatukova et al., 2009).

Early works have focused on estimating the relative contributions of specific sources to CSO pollutant load in terms of total amount of heavy metals, hydrocarbons, nutrients. Such an approach only provides a rough assessment of contaminant mobility and bioavailability in receiving waters, since pollutant behavior is mainly governed by its speciation (Revitt and Morrison, 1987; El Samrani et al., 2004).

Metal ions in sediments are partitioned between different chemical components (organic matter, oxyhydroxides of iron, aluminium and manganese, phyllosilicate minerals, carbonates, sulfides, etc.) and retained by these solid phases through different mechanisms (adsorption, complexation, precipitation, etc.) which determine their mobilization capacity and bioavailability (Morillo et al., 2002; Filgueiras et al., 2004). Exchangeable forms are usually considered as immediately bioavailable species. The partitioning of metal contaminants between specific forms is classically determined using sequential extraction methods by adding appropriate reagents to the sample. Despite the fact that metal fractions obtained by selective chemical extraction procedures are only operationally defined, as incomplete dissolution of the target phase, dissolution of nontarget species, incomplete removal of dissolved species due to readsorption or precipitation may occur, sequential extraction methods provide valuable information about the distribution and mobility of metals in sediments (Rauret et al., 1999; Sahuquillo et al., 2003).

\subsection{Study area}

Prague urban area has a total population of about 1.25 million inhabitants. About $98 \%$ of this population is connected to the sewer system, which conducts wastewaters downstream Prague to the central treatment plant. Since 1966, the central treatment plant is situated on the Císařský island, which is located in the northern part of Prague on the Vltava River. During strong rain events polluted waste water is discharged into the Vltava River and its tributaries through CSO from the central unitary sewer system with total length of about $2900 \mathrm{~km}$ and at the outlet of catchments with separate sewer systems in the newer outer part of the conurbation. There is total number of 132 CSOs (52 CSOs discharge to Vltava River, 80 CSOs discharge to its tributaries) and 230 storm sewer outlets in Prague sewers system.

Three urban streams, the Botič, Rokytka and Kunratický, are right-hand tributaries of the Vltava River (catchment area of $28090 \mathrm{~km}^{2}$, mean flow $150 \mathrm{~m}^{3} \mathrm{~s}^{-1}$ at the confluence with the Elbe River) in Prague, the capital of the Czech Republic (Fig. 1). The Botič and Rokytka streams are two largest tributaries of the Vltava River within the Prague agglomeration with lengths of $34.5 \mathrm{~km}$ and 36.2 $\mathrm{km}$, and catchment areas of $135 \mathrm{~km}^{2}$ and $132 \mathrm{~km}^{2}$, respectively. The discharge of both streams at their confluence is approximately equivalent, with annual mean discharge of $0.40 \mathrm{~m}^{3} \mathrm{~s}^{-1}$ at Botič and 0.45 $\mathrm{m}^{3} \mathrm{~s}^{-1}$ at Rokytka stream. The Botič stream, which is the most affected stream by urban drainage in 


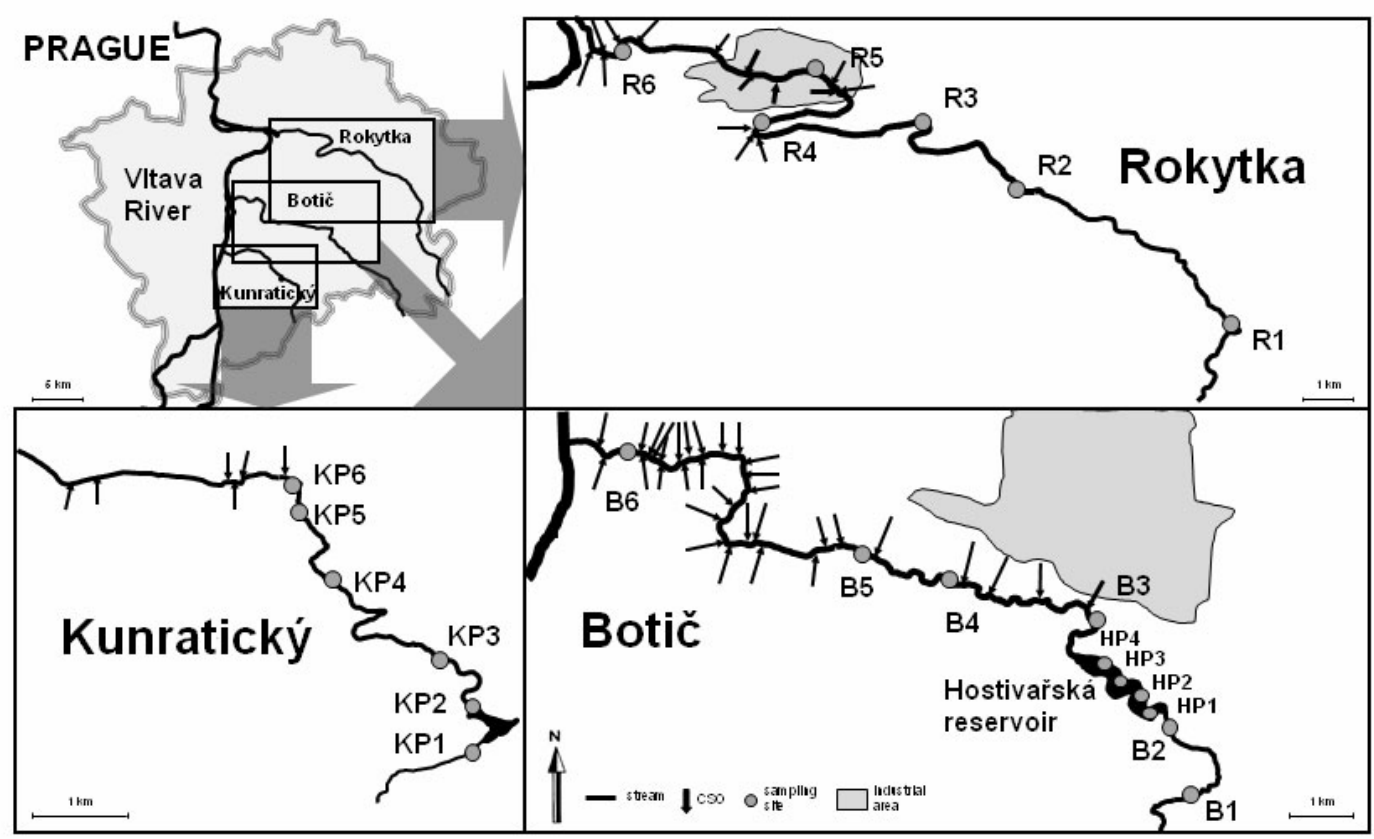

Fig. 1. Location of the studied catchments, sampling sites and combined sewer overflows.

Prague, receives the discharge of 33 CSOs (annual mean overflow volume of $412000 \mathrm{~m}^{3}$ year $^{-1}$, maximum flow of CSO $2.02 \mathrm{~m}^{3} \mathrm{~s}^{-1}$ ) while the Rokytka stream receives the discharge of $15 \mathrm{CSOs}$ (annual mean overflow volume of $185000 \mathrm{~m}^{3}$ year $^{-1}$, maximum flow of CSO $1.96 \mathrm{~m}^{3} \mathrm{~s}^{-1}$ ). There are also several storm sewer outlets discharging to both streams. There is agricultural activity in the upstream areas of both streams, and urbanized downstream areas are influenced by the wastewaters of printing, electrical, chemical and machine-building industries through CSOs. The third assessed stream is the Kunratický stream $\left(14.8 \mathrm{~km}\right.$ length, $31.6 \mathrm{~km}^{2}$ catchment area, $0.18 \mathrm{~m}^{3} \mathrm{~s}^{-1}$ mean discharge) which runs through wooded and partially residential areas, and receives the discharge of only $6 \mathrm{CSO}$ in the downstream area and several storm sewer outlets.

The basic objectives of this study conducted with the sediments from three urban streams in Prague were (i) to investigate metal pollution load and environmental risk, and (ii) to assess the influence of CSO discharge on the distribution and mobility of heavy metals in sediments. An investigation of the concentrations of six heavy metals $(\mathrm{Cd}, \mathrm{Cr}, \mathrm{Cu}$, $\mathrm{Pb}, \mathrm{Ni}, \mathrm{Zn}$ ) in stream sediments was coupled with sequential extraction analyses, investigation of physico-chemical parameters and mineralogical analysis by X-ray powder diffraction analysis
(XRD). The multivariate data analysis technique of clustering was used in the classification of polluting characteristics, the quantitative identification of specific areas of contamination, and the impact of CSOs.

\section{Materials and methods \\ 2.1 Sediment sampling and processing}

A total of 44 stream sediments in two replicates were sampled up to $5 \mathrm{~cm}$ in depth from three urban streams and the Hostivařská reservoir (Fig. 1). The stream sediments were sampled at six sampling sites in each stream and at four sampling sites of the Hostivařská reservoir, using a plastic trowel. For the Botič and Rokytka streams, the first three sampling sites were chosen in the upstream area above the discharge of the first CSO, and the other three sampling sites were chosen in the downstream area below the discharge of a number of CSOs. Moreover, four sampling sites were located in the Hostivarská reservoir which is situated in the upper part of the Botič stream. Six sampling sites located in the Kunratický stream were not affected by CSOs. These sites were chosen in order to compare metal distribution in urban streams affected by CSOs with the urban stream non-affected by CSOs. 
Sediment samples were collected into clean polyethylene containers and frozen immediately on returning to the laboratory. The samples were then freeze dried, and the fine fraction was separated by sieving through a $63 \mu \mathrm{m}$ mesh nylon sieve in order to obtain the chemically active sediment phase, consisting primarily of clay and silt particulates.

\subsection{Total metal concentrations}

For total metal concentration determinations, the sediments were digested following the MW EPA 3052 digestion method, modified by the addition of $\mathrm{H}_{3} \mathrm{BO}_{3}$ in order to avoid the formation of insoluble fluorides. A mass of $0.5 \mathrm{~g}$ of sediment sample was dissolved in $9 \mathrm{ml} \mathrm{HNO}_{3}, 3 \mathrm{ml} \mathrm{HF}, 3 \mathrm{ml} \mathrm{HCl}$ and 1.2 $\mathrm{g}$ of $\mathrm{H}_{3} \mathrm{BO}_{3}$ in $50 \mathrm{ml}$ PTFE high-pressure digestion bombs for microwave digestion (Milestone Ethos TC, USA) at $175^{\circ} \mathrm{C}$ for $15 \mathrm{~min}$. The digests were filtered, adjusted to $50 \mathrm{ml}$ with deionised MilliQ water and stored at $4{ }^{\circ} \mathrm{C}$ in polypropylene bottles until analysis. A procedural blank was submitted to the same digestion procedures. The concentrations of $\mathrm{Cd}, \mathrm{Cr}, \mathrm{Cu}, \mathrm{Ni}, \mathrm{Pb}$ and $\mathrm{Zn}$ were determined using the ICP-MS technique (PQ 3 VG Elemental, England). The relative standard deviations (RSDs) for duplicate measurements of 10 randomly selected replicates were lower than $10 \%$ for all metals.

\subsection{Sequential extraction method}

The chemical fractionation of metals in 22 sediment samples was determined using the BCR sequential extraction method (Rauret et al., 1999), which consists of three successive extractions. Each chemical fraction was operationally defined as: acid soluble phase/exchangeable or bound to carbonates (Fraction 1), reducible phase/bound to $\mathrm{Fe}$ and $\mathrm{Mn}$ oxides (Fraction 2), oxidisable phase/bound to organic matter or sulfides (Fraction 3) (Fig. 2). Furthermore, a fourth residual phase (Fraction 4) was determined by a total digestion according to the EPA 3052 method, in order to determine the amount of metals associated with primary minerals, which are unlikely to be released from sediments. The accuracy of the sequential extraction was checked using the freshwater sediment reference material CRM 701 (SM\&T, EU) in four replicates which were digested simultaneously with the sediment samples and analyzed under the same conditions. The recovery rates for heavy metals in the standard reference material were between $92 \%$ and
$112 \%$. In order to determine the precision of the analytical processes, three samples were analysed in triplicate. The average values of the variation coefficients obtained (in general, less than 10\%) can be considered satisfactory for environmental analysis.

\subsection{Physico-chemical properties and mineralogy}

Sediment $\mathrm{pH}$ was measured in a water suspension using a $1: 2(v / v)$ ratio of sediment and deionized water. Organic matter content in the sediment was determined gravimetrically as the loss on ignition (LOI) at $450{ }^{\circ} \mathrm{C}$ of $3 \mathrm{~g}$ of the freeze dried subsamples. The content of total $\mathrm{N}$ and total $\mathrm{P}$ were determined spectrophometrically using a Skalar spectrophometer after mineralization. Cation exchange capacity (CEC) was determined as the sum of basic cations and $\mathrm{Al}$ extracted with a $0.1 \mathrm{M}$ $\mathrm{BaCl}_{2}$ solution and the extractable acidity. Acid oxalate extraction was performed with $0.2 \mathrm{M}$ ammonium oxalate/oxalate acid at $\mathrm{pH} 3$. Obtained oxalate extracts were analysed for $\mathrm{Fe}, \mathrm{Al}$ and $\mathrm{Mn}$ by a Varian 240 flame atomic absorption spectrophotometer. X-ray powder diffraction analysis (XRD) was performed on selected samples using an $X$ 'Pert Pro (PANalytical, Holland) with a secondary graphite monochromator with $\mathrm{CuK} \alpha$ radiation over the range from $3-60^{\circ} 2 \Theta$. Qualitative identification of crystalline phases present using the HighScore software package and evaluation of the semiquantitative mineralogical composition were performed.

\subsection{Data analysis}

In order to evaluate the environmental risk of sediment metal contamination, the Hazard Quotient (HQ) was calculated in agreement with Barnthouse et al. (1982) as:

$$
H Q=\frac{C_{\text {sed }}}{S E C},
$$

where $\mathrm{C}_{\text {sed }}$ is the metal concentration in the stream sediment and SEC - Sediment Effect Concentration represents US EPA toxicological benchmarker of TEC - Treshold Effect Concentration (Jones et al., 1997). If the risk of six metals together is assessed, increased risk occurs when HQ exceeds 6 .

The mobility of observed heavy metals in sediments was assessed by the Mobility Factor (MF), which compares the weakly bound fractions with 


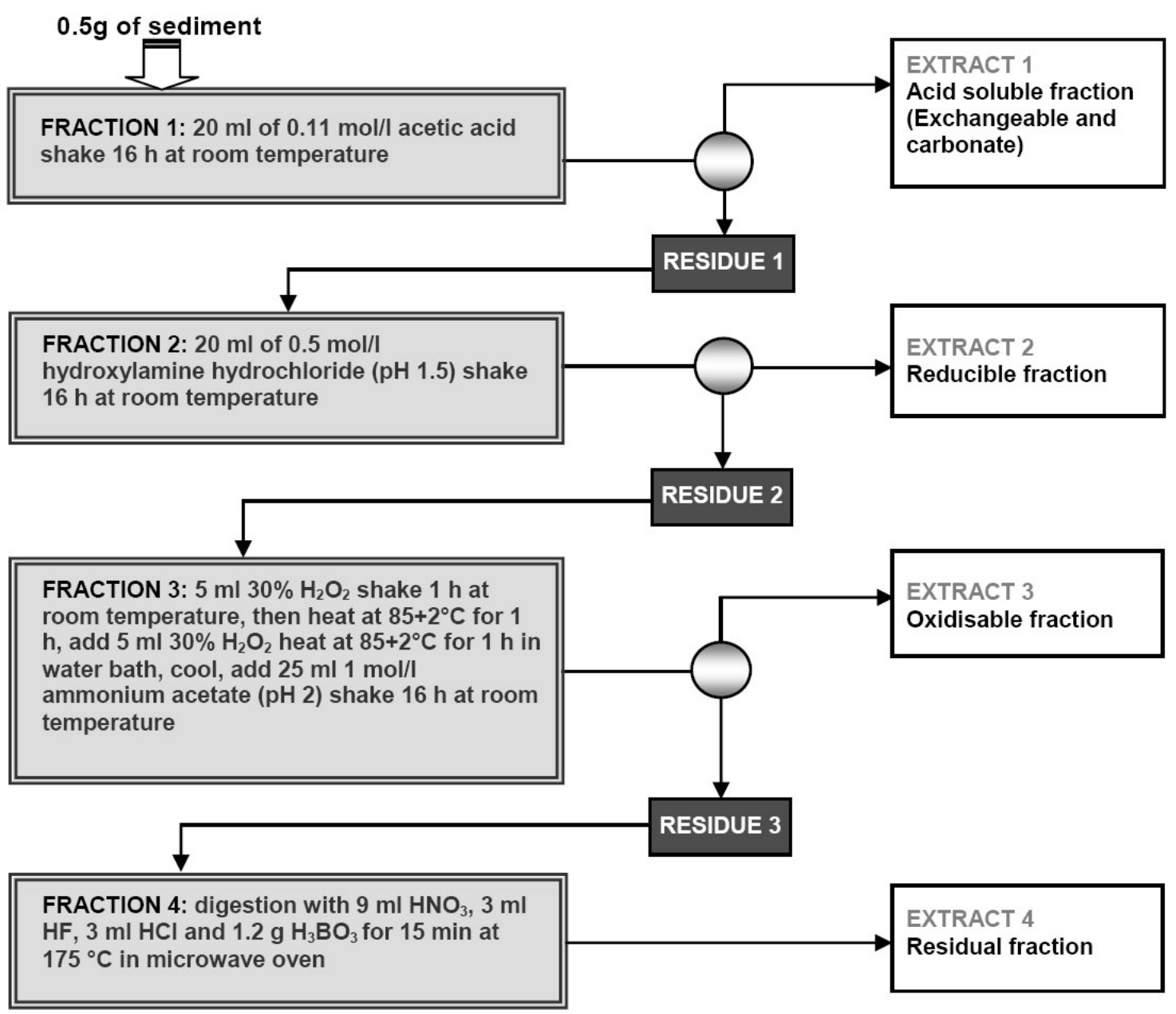

Fig. 2. Sequential extraction scheme.

the total metal content. Exchangeable and acid extractable fractions are considered as easily available. Therefore, MF was calculated according to Kabala and Singh (2001):

$M F=\frac{\text { Fraction } 1}{\sum \text { frations }} 100[\%]$,

where Fraction 1 is the amount of metal bound to acid soluble/exchangable and carbonate fraction and $\Sigma$ fractions is the sum of all sequential extraction fractions.

One way ANOVA was used for comparison of differences in metal pollution levels of observed streams. The hierarchical cluster analysis based on unweighted pair-group average method in Statistica program was employed to quantitatively identify specific areas of metal contamination and for the recognition of variable structures of metal pollution in order to evaluate CSO impact.

\section{Results and discussion}

The results in Tab. 1 present mean values of selected physico-chemical properties and mineralogy of sediments. The sediment $\mathrm{pH}$ values were circumneutral and ranged from 6.5 to 7.8 . The presence of calcite $\left(\mathrm{CaCO}_{3}\right)$ detected by XRD analysis in the Rokytka sediments probably causes relatively higher mean values of measured $\mathrm{pH}$ and CEC. The contents of oxalate-extractable $\mathrm{Fe}, \mathrm{Al}$ and $\mathrm{Mn}$ were also higher in the Rokytka stream sediments compared to the others.

Tab. 2 shows total concentrations of $\mathrm{Cd}, \mathrm{Cr}, \mathrm{Cu}$, $\mathrm{Ni}, \mathrm{Pb}$ and $\mathrm{Zn}$ in the studied sediments, as well as calculated Hazard Quotients and Mobility Factors. Metal concentrations in the longitudinal profile of the Botič and Rokytka streams show significant increase due to discharge of CSOs. The highest concentrations of $\mathrm{Cu}, \mathrm{Zn}$ and $\mathrm{Pb}$ were found in the downstream sampling profiles in the Botič and Ro- 
$\mathrm{T} \mathrm{a} \mathrm{b} \mathrm{l} \mathrm{e} \mathrm{1.} \mathrm{Mean} \mathrm{and} \mathrm{standard} \mathrm{deviation} \mathrm{of} \mathrm{selected} \mathrm{physico-chemical} \mathrm{parameters} \mathrm{and} \mathrm{mineralogy} \mathrm{of} \mathrm{sediments.}$

\begin{tabular}{|c|c|c|c|c|c|c|c|c|c|}
\hline \multirow[t]{2}{*}{ Stream } & \multicolumn{3}{|c|}{ Oxalate-extractable $\left(\mathrm{g} \mathrm{kg}^{-1}\right)$} & \multirow{2}{*}{$\begin{array}{l}\mathrm{N}_{\text {tot. }} \\
{[\%]}\end{array}$} & \multirow{2}{*}{$\begin{array}{c}\mathrm{P}_{\text {tot. }} \\
{\left[\mathrm{g} \mathrm{kg}^{-1}\right]}\end{array}$} & \multirow{2}{*}{$\begin{array}{l}\text { LOI } \\
{[\%]}\end{array}$} & \multirow{2}{*}{$\begin{array}{c}\mathrm{CEC} \\
{\left[\mathrm{cmol} \mathrm{kg}^{-1}\right]}\end{array}$} & \multirow[t]{2}{*}{$\mathrm{pH}$} & \multirow{2}{*}{$\begin{array}{l}\text { Mineralogical } \\
\text { phases (XRPD) }\end{array}$} \\
\hline & $\mathrm{Fe}_{0}$ & $\mathrm{Al}_{0}$ & $\mathrm{Mn}_{0}$ & & & & & & \\
\hline Botič & $4.3 \pm 1.3$ & $0.5 \pm 0.1$ & $0.4 \pm 0.1$ & $0.15 \pm 0.02$ & $0.8 \pm 0.2$ & $8.8 \pm 2.6$ & $11 \pm 2$ & $6.8 \pm 0.2$ & $\begin{array}{l}\text { Q., Mus., Mic., } \\
\text { Alb., K., Chl. }\end{array}$ \\
\hline Rokytka & $14 \pm 3$ & $1.5 \pm 0.4$ & $0.8 \pm 0.4$ & $0.32 \pm 0.14$ & $3.6 \pm 2.3$ & $8.3 \pm 2.3$ & $18 \pm 4$ & $7.2 \pm 0.2$ & $\begin{array}{l}\text { Q., Cal., Mus., } \\
\text { Mic. Alb., K. }\end{array}$ \\
\hline Kunratický & $5.5 \pm 1.8$ & $0.9 \pm 0.5$ & $0.3 \pm 0.1$ & $0.25 \pm 0.14$ & $1.2 \pm 0.5$ & $9.2 \pm 1.9$ & $14 \pm 3$ & $7.1 \pm 0.3$ & $\begin{array}{l}\text { Q., Mus., Mic., } \\
\text { Alb., K. }\end{array}$ \\
\hline $\begin{array}{l}\text { Hostivařská } \\
\text { reservoir }\end{array}$ & $6.3 \pm 1.4$ & $0.9 \pm 0.1$ & $0.4 \pm 0.1$ & $0.19 \pm 0.11$ & $1.0 \pm 0.5$ & $6.3 \pm 0.8$ & $13 \pm 2$ & $6.9 \pm 0.2$ & $\begin{array}{l}\text { Q., Mus., Mic., } \\
\text { Alb., K., Chl. }\end{array}$ \\
\hline
\end{tabular}

$\mathrm{T}$ a b 1 e 2. Mean values of total metal concentration and standard deviation of measurements $(n=2)$, Hazard Quotient (HQ) and Mobility Factor (MF) for sediments.

\begin{tabular}{|c|c|c|c|c|c|c|c|c|c|c|c|c|c|c|c|c|c|c|c|}
\hline Sample & $\begin{array}{l}\mathrm{Cu} \\
{\left[\mathrm{mg} \mathrm{kg}^{-1}\right]}\end{array}$ & HQ & MF & $\begin{array}{l}\mathrm{Zn} \\
{\left[\mathrm{mg} \mathrm{kg}^{-1}\right]}\end{array}$ & HQ & MF & $\begin{array}{l}\mathrm{Pb} \\
{\left[\mathrm{mg} \mathrm{kg}^{-1}\right]}\end{array}$ & HQ & MF & $\begin{array}{l}\mathrm{Cd} \\
{\left[\mathrm{mg} \mathrm{kg}^{-1}\right]}\end{array}$ & HQ & MF & $\begin{array}{l}\mathrm{Cr} \\
{\left[\mathrm{mg} \mathrm{kg}^{-1}\right]}\end{array}$ & HQ & MF & $\begin{array}{l}\mathrm{Ni} \\
{\left[\mathrm{mg} \mathrm{kg}^{-1}\right]}\end{array}$ & HQ & MF & $\Sigma \mathrm{HQ}$ \\
\hline \multicolumn{20}{|l|}{ Botič } \\
\hline B1 & $16 \pm 3$ & 0.6 & 7.7 & $79 \pm 11$ & 0.5 & 14.3 & $24 \pm 5$ & 0.7 & 0.6 & $0.3 \pm 0.1$ & 0.4 & 46.2 & $31 \pm 8$ & 0.6 & 1.2 & $17 \pm 1$ & 0.4 & 10.3 & 3.2 \\
\hline B2 & $20 \pm 6$ & 0.7 & 9.3 & $101 \pm 5$ & 0.6 & 18.9 & $20 \pm 7$ & 0.6 & 2.9 & $0.2 \pm 0.1$ & 0.4 & 50.0 & $29 \pm 11$ & 0.5 & 2.0 & $21 \pm 6$ & 0.5 & 20.3 & 3.4 \\
\hline B3 & $32 \pm 4$ & 1.1 & 8.4 & $110 \pm 24$ & 0.7 & 17.9 & $22 \pm 2$ & 0.6 & 1.1 & $0.2 \pm 0.0$ & 0.3 & 40.0 & $20 \pm 1$ & 0.4 & 1.2 & $17 \pm 2$ & 0.4 & 14.1 & 3.5 \\
\hline B4 & $86 \pm 10$ & 3.1 & 8.7 & $274 \pm 21$ & 1.7 & 31.7 & $53 \pm 4$ & 1.6 & 1.3 & $0.6 \pm 0.3$ & 1.0 & 45.7 & $32 \pm 8$ & 0.6 & 1.0 & $25 \pm 4$ & 0.6 & 11.8 & 8.6 \\
\hline B5 & $116 \pm 19$ & 4.1 & 5.8 & $293 \pm 33$ & 1.8 & 33.8 & $78 \pm 16$ & 2.3 & 4.9 & $0.5 \pm 0.0$ & 0.9 & 43.9 & $40 \pm 8$ & 0.7 & 1.2 & $28 \pm 3$ & 0.7 & 11.6 & 10.6 \\
\hline B6 & $135 \pm 3$ & 4.7 & 4.6 & $446 \pm 3$ & 2.8 & 35.5 & $88 \pm 2$ & 2.6 & 1.4 & $0.8 \pm 0.1$ & 1.5 & 40.7 & $61 \pm 2$ & 1.1 & 1.3 & $41 \pm 4$ & 1.1 & 16.6 & 13.9 \\
\hline \multicolumn{20}{|l|}{ Rokytka } \\
\hline R1 & $48 \pm 17$ & 1.7 & 4.4 & $188 \pm 29$ & 1.2 & 38.6 & $28 \pm 11$ & 0.8 & 1.0 & $0.4 \pm 0.2$ & 0.7 & 44.7 & $29 \pm 5$ & 0.5 & 0.2 & $23 \pm 3$ & 0.6 & 12.2 & 5.5 \\
\hline R2 & $77 \pm 12$ & 2.8 & 4.0 & $279 \pm 21$ & 1.7 & 35.6 & $56 \pm 3$ & 1.6 & 0.7 & $0.9 \pm 0.2$ & 1.5 & 42.5 & $41 \pm 4$ & 0.7 & 0.1 & $37 \pm 2$ & 0.9 & 19.3 & 9.3 \\
\hline R3 & $60 \pm 1$ & 2.2 & 6.5 & $276 \pm 3$ & 1.7 & 33.9 & $68 \pm 2$ & 2.0 & 1.3 & $0.8 \pm 0.1$ & 1.4 & 34.3 & $47 \pm 13$ & 0.8 & 1.0 & $30 \pm 1$ & 0.8 & 18.5 & 8.9 \\
\hline R4 & $114 \pm 15$ & 4.1 & 1.6 & $386 \pm 39$ & 2.4 & 41.9 & $57 \pm 3$ & 1.7 & 0.3 & $1.6 \pm 0.2$ & 2.7 & 65.1 & $58 \pm 3$ & 1.0 & 0.1 & $42 \pm 2$ & 1.0 & 25.7 & 13.0 \\
\hline R5 & $85 \pm 2$ & 3.0 & 4.8 & $341 \pm 20$ & 2.1 & 32.1 & $64 \pm 10$ & 1.9 & 1.5 & $0.8 \pm 0.2$ & 1.3 & 39.5 & $40 \pm 8$ & 0.7 & 0.2 & $35 \pm 3$ & 0.7 & 16.9 & 10.0 \\
\hline R6 & $98 \pm 11$ & 3.5 & 4.1 & $399 \pm 34$ & 2.5 & 29.8 & $114 \pm 24$ & 3.3 & 1.5 & $1.9 \pm 0.5$ & 3.2 & 38.8 & $43 \pm 8$ & 0.8 & 0.3 & $35 \pm 6$ & 0.8 & 13.4 & 14.3 \\
\hline \multicolumn{20}{|c|}{ Kunratický } \\
\hline KP1 & $126 \pm 30$ & 4.5 & 10.5 & $187 \pm 26$ & 1.2 & 25.3 & $35 \pm 6$ & 1.0 & 12.1 & $2.4 \pm 1.0$ & 4.0 & 50.0 & $37 \pm 7$ & 0.7 & 1.3 & $36 \pm 9$ & 0.9 & 19.2 & 12.3 \\
\hline KP2 & $88 \pm 18$ & 3.1 & 5.0 & $186 \pm 29$ & 1.2 & 18.8 & $19 \pm 5$ & 0.6 & 16.7 & $3.2 \pm 0.8$ & 5.3 & 45.2 & $27 \pm 7$ & 0.5 & 1.3 & $29 \pm 1$ & 0.7 & 17.7 & 11.4 \\
\hline KP3 & $63 \pm 13$ & 2.3 & 7.4 & $214 \pm 14$ & 1.3 & 34.7 & $39 \pm 2$ & 1.1 & 5.0 & $1.4 \pm 0.3$ & 2.4 & 48.2 & $28 \pm 7$ & 0.5 & 2.1 & $26 \pm 3$ & 0.7 & 16.6 & 8.3 \\
\hline KP4 & $40 \pm 4$ & 1.4 & 3.2 & $160 \pm 4$ & 1.0 & 21.7 & $30 \pm 1$ & 0.9 & 4.5 & $1.0 \pm 0.2$ & 1.7 & 53.3 & $28 \pm 1$ & 0.5 & 1.6 & $26 \pm 1$ & 0.7 & 24.5 & 6.2 \\
\hline KP5 & $85 \pm 12$ & 3.0 & 7.1 & $214 \pm 20$ & 1.3 & 28.9 & $37 \pm 7$ & 1.1 & 9.6 & $0.7 \pm 0.1$ & 1.2 & 38.2 & $27 \pm 4$ & 0.5 & 1.6 & $22 \pm 2$ & 0.5 & 14.6 & 7.7 \\
\hline KP6 & $73 \pm 1$ & 2.6 & 3.6 & $179 \pm 14$ & 1.1 & 22.8 & $40 \pm 1$ & 1.2 & 3.8 & $0.8 \pm 0.1$ & 1.3 & 41.3 & $29 \pm 3$ & 0.5 & 1.2 & $33 \pm 7$ & 0.8 & 11.7 & 7.5 \\
\hline \multicolumn{20}{|c|}{ Hostivařská reservoir } \\
\hline HP1 & $18 \pm 3$ & 0.6 & 7.2 & $102 \pm 16$ & 0.6 & 25.2 & $26 \pm 4$ & 0.8 & 1.0 & $0.3 \pm 0.1$ & 0.5 & 71.4 & $34 \pm 5$ & 0.6 & 1.5 & $17 \pm 3$ & 0.4 & 5.1 & 3.6 \\
\hline HP2 & $22 \pm 7$ & 0.8 & 5.7 & $100 \pm 5$ & 0.6 & 15.2 & $29 \pm 7$ & 0.8 & 0.7 & $0.3 \pm 0.1$ & 0.5 & 64.3 & $41 \pm 8$ & 0.7 & 1.4 & $22 \pm 3$ & 0.6 & 4.1 & 4.1 \\
\hline HP3 & $22 \pm 3$ & 0.8 & 1.9 & $81 \pm 14$ & 0.5 & 5.5 & $29 \pm 2$ & 0.9 & 0.7 & $0.1 \pm 0.0$ & 0.2 & 42.9 & $65 \pm 14$ & 1.2 & 0.8 & $35 \pm 4$ & 0.9 & 1.6 & 4.4 \\
\hline HP4 & $16 \pm 4$ & 0.6 & 1.7 & $70 \pm 8$ & 0.4 & 9.0 & $39 \pm 6$ & 1.1 & 1.3 & $0.2 \pm 0.1$ & 0.4 & 47.6 & $37 \pm 4$ & 0.7 & 0.4 & $17 \pm 2$ & 0.4 & 3.7 & 3.6 \\
\hline
\end{tabular}

kytka streams (samples B6, R6 and R4), up to $141.8 \mathrm{mg} \mathrm{Cu} \mathrm{kg}^{-1}, 452.2 \mathrm{mg} \mathrm{Zn} \mathrm{kg}{ }^{-1}$, and $137.2 \mathrm{mg}$ $\mathrm{Pb} \mathrm{kg}{ }^{-1}$. The highest concentrations of $\mathrm{Cd}$, up to 3.9

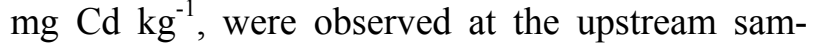
pling sites KP1 and KP2 of the Kunratický stream. High Cd concentrations, up to $5.6 \mu \mathrm{g} \mathrm{l}^{-1}$, in water at upstream profiles of the Kunratický stream reported Sánka (1991) during geochemical survey. Considerable $\mathrm{Cd}$ contamination of this locality is probably related to the long history of plating industry and precious metal processing in nearby Vestec municipality since 1950. Metal levels indicate low metal contamination by $\mathrm{Cr}$ and $\mathrm{Ni}$ in all streams because they are near to natural levels (Fergusson, 1990).
The risk assessment of heavy metals according to HQ (using TEC criterion) indicates possible impact of contaminated sediments on stream environment, as Fig. 3 shows. CSO impact on increased sediment toxicity of the Botič and Rokytka streams is evident. $\mathrm{Cu}$ toxicity dominates at downstream profiles of the Botič stream, $\mathrm{Cu}$ and $\mathrm{Cd}$ toxicity dominates at profiles R4 and R6 of the Rokytka stream. Besides these metals, $\mathrm{Pb}$ and $\mathrm{Zn}$ were found as important pollutants in both these streams. Increased risk and dominant toxicity of $\mathrm{Cu}$ and $\mathrm{Pb}$ below the discharge of CSOs in the Botič stream sediments have been presented in previous study of Nábèlková et al. (2004). HQ values of the Hostivařská reservoir sediments do not indicate environmental risk, which 

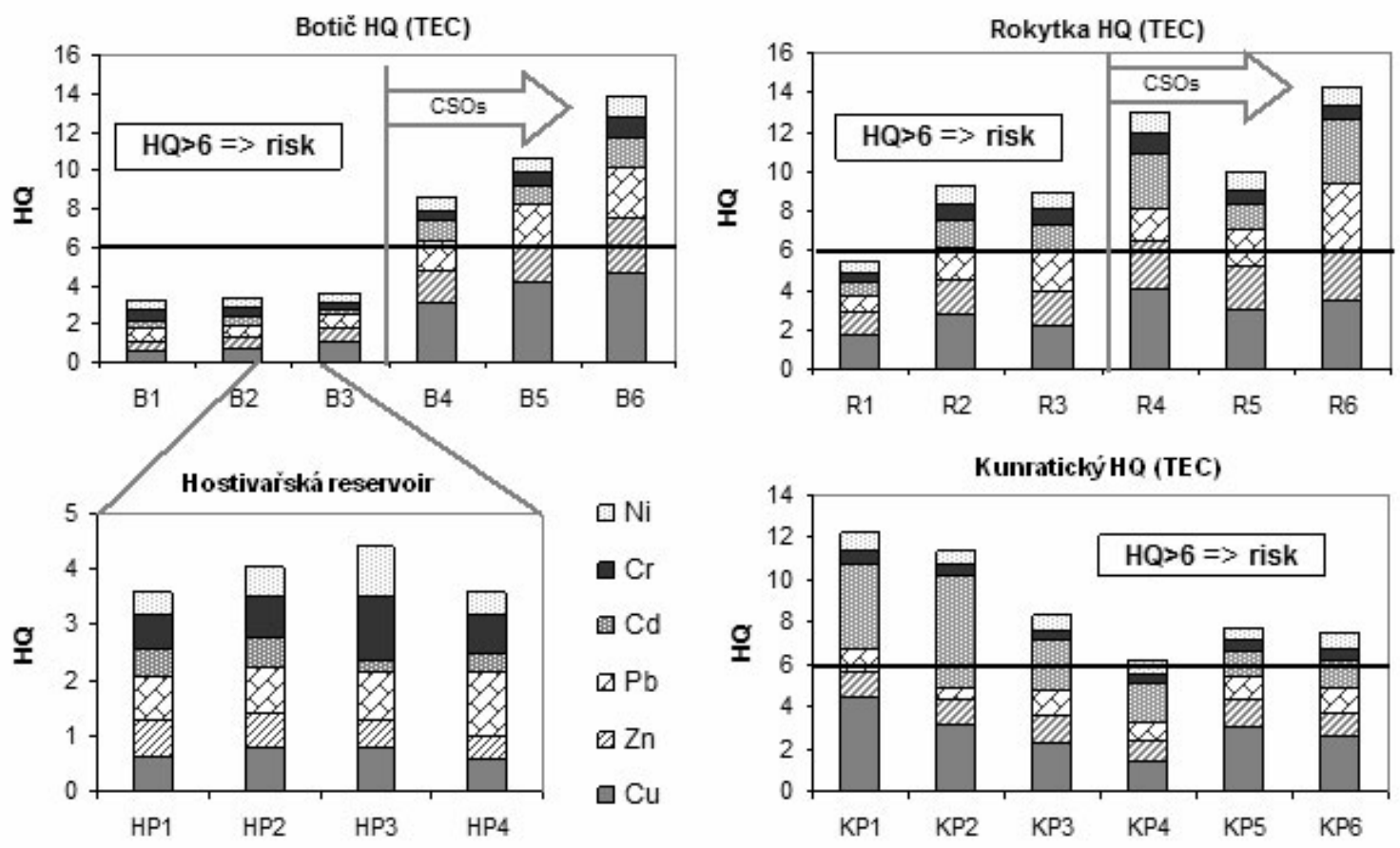

Fig. 3. Environmental risk assessment of heavy metals in sediments according to HQ (using TEC criterion).

corresponds to low contamination of nearby profiles of the Botič stream B2 and B3. Significant contamination of upper part of the Kunratický stream is presented by high HQ values of $\mathrm{Cd}$ and $\mathrm{Cu}$ at profiles KP1 and KP2.

One way ANOVA was used for comparison of overall environmental risk of stream sediments expressed as $\Sigma \mathrm{HQ}$. Normality of data as one of preconditions of one way ANOVA method was tested by Kolmogorov-Smirnov test and was not rejected at $5 \%$ probability level ( $p$-value $=0.5)$. Independence between $\Sigma \mathrm{HQ}$ values and an affiliation of sampling site to specific stream was not rejected ( $p$-value $=0.3$ ), so the $\Sigma \mathrm{HQ}$ variance among sampling sites in longitudinal profile of each stream was greater than the $\Sigma \mathrm{HQ}$ variance among observed streams. Variance of $\Sigma \mathrm{HQ}$ values between three upper and three lower sampling sites of streams affected by CSOs - the Botič and Rokytka streams was also tested in order to evaluate CSO impact. The lower sampling sites of both streams, already affected by CSOs, were significantly heavily contaminated $(p$-value $=0.01)$. No statistically significant relationships between physico-chemical properties of sediments and metal concentrations were observed. This fact probably indicates that other factors such as the impact of urban drainage more significantly influence the stream sediment contamination level.

The hierarchical cluster analysis was employed to quantify CSO impact and identify any specific areas of contamination. Fig. 4 shows dendogram produced by cluster analysis, where four major clusters were detected (A-D). T-transformation $(t=$ $\left.=x / x_{\max }\right)$ was applied in order to remove the natural weights of metals. The cluster A presents most contaminated profiles with highly elevated concentrations of $\mathrm{Cu}, \mathrm{Zn}, \mathrm{Pb}$ and $\mathrm{Cd}$ in sediments. This cluster includes downstream profiles of the Rokytka (R6, R4) and the Botič (B5) streams affected by most of located CSOs. The cluster B comprises two profiles of the Kunratický stream (KP1, KP2), where cadmium concentrations are twice the averages of cluster A, showing high cadmium contamination. The cluster $\mathrm{C}$ representing intermediate contamination level can be sub-divided in two $(\mathrm{C} 1$, $\mathrm{C} 2$ ). $\mathrm{C} 1$ includes R2, R3, R5 and B5 profiles of higher concentrations of $\mathrm{Cu}, \mathrm{Pb}$ and $\mathrm{Zn}$ than less contaminated profiles comprised in $\mathrm{C} 2$. The cluster $\mathrm{D}$ includes upper profiles of the Rokytka and the Botič streams which present the lowest metal concentration level. 


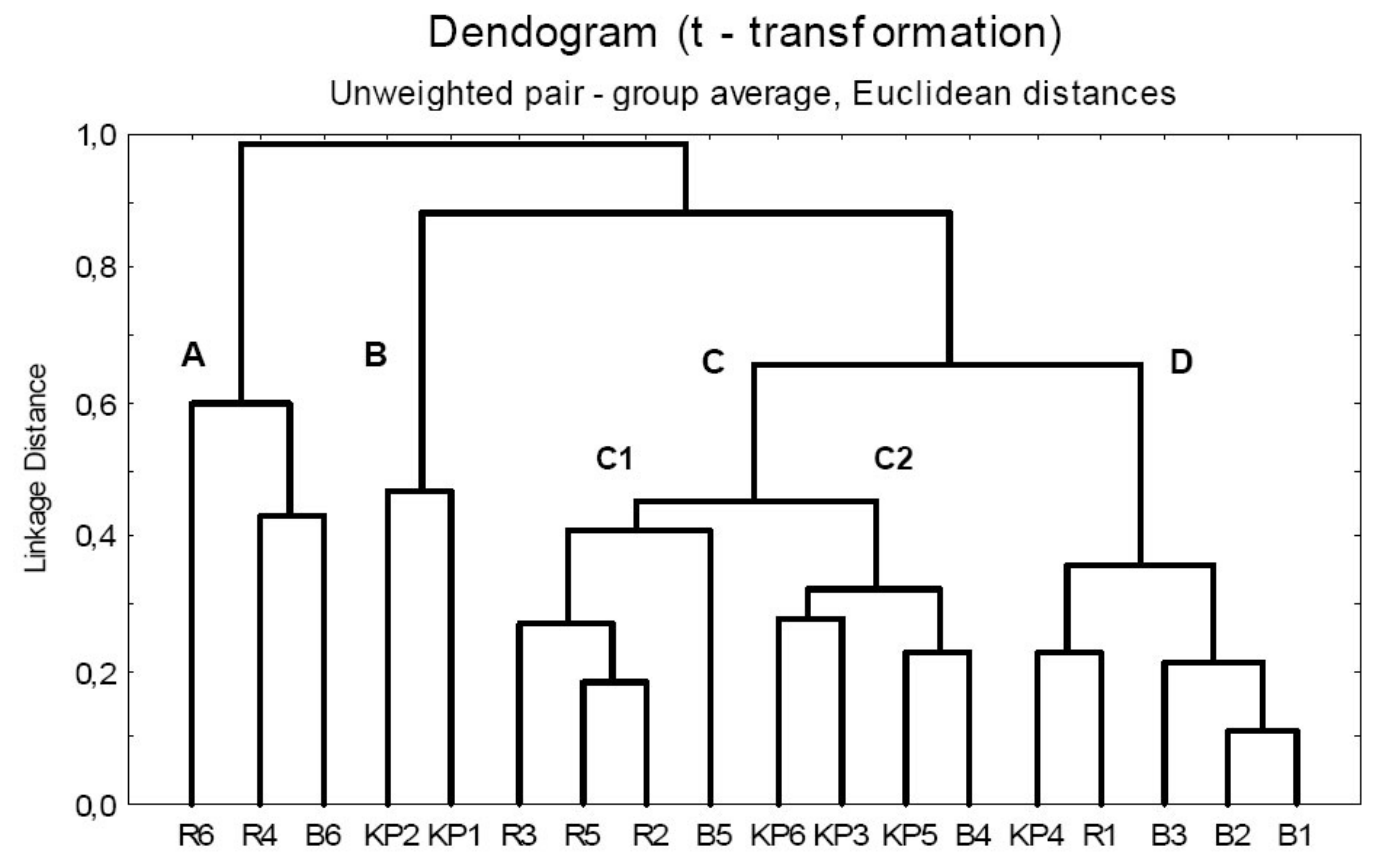

Fig. 4. Dendogram obtained by cluster anaylsis, four major clusters (A-D) identified.

The observed mobility order of six metals according to calculated mobility factor was $\mathrm{Cd}>\mathrm{Zn}>$ $>\mathrm{Ni}>\mathrm{Cu}>\mathrm{Pb}>\mathrm{Cr}$ (Tab. 2). Cadmium was revealed as the most mobile heavy metal in all streams with percentages of extraction of approximately $40-60 \%$ in acid soluble fraction. However for $\mathrm{Cu}, \mathrm{Pb}$ and $\mathrm{Cr}$, the extracted percentages did not exceed, in general, $10 \%$. There was a considerable increase in $\mathrm{Zn}$ mobility from $15 \%$ to $40 \%$ in the Botič stream sediments in the profiles below CSOs discharge. Stead-Dexter and Ward (2004) also reported that $\mathrm{Zn}$ exhibited an increase in the more easily available fractions through drainage systems and stormwater. Cadmium and zinc were found as the most dangerous metals for the aquatic environment according to their high potential for remobilization to aqueous phase. A high mobility of $\mathrm{Cd}$ and $\mathrm{Zn}$ associated with easily extractable fractions (exchangeable or carbonate) has been also reported by other authors (Morillo et al., 2002; Jain, 2004; Lee et al., 2005). High mobility of $\mathrm{Zn}$ in the longitudinal profile of the Rokytka stream can be related to the occurrence of carbonates analysed by XRD (Tab. 1). Zinc may be found as co-precipitated with carbonate minerals in acid soluble fraction (Ure et al., 1993).

Fig. 5 shows the results of sequential extraction as chemical speciation of $\mathrm{Cu}, \mathrm{Zn}, \mathrm{Pb}, \mathrm{Cd}, \mathrm{Cr}$ and $\mathrm{Ni}$ in sediments of the studied urban streams. Reduci- ble fraction was found to be dominant in speciation of $\mathrm{Pb}$ in all streams with approximately $50-70 \%$ extractable amount of total $\mathrm{Pb}$ content. High association of $\mathrm{Pb}$ with $\mathrm{Fe} / \mathrm{Mn}$-oxide phase is indicative of anthropogenic pollution (Gómez-Ariza et al., 2000; Ettler et al., 2006). Chromium and Ni were found to be associated mainly with residual fraction, up to $85 \%$ of the total speciation for $\mathrm{Cr}$ and $60 \%$ for $\mathrm{Ni}$. Together with low HQ values for $\mathrm{Cr}$ and $\mathrm{Ni}$, this indicates probable natural origin of these metals (Farkas et al., 2007). There was a considerable increase of amount of $\mathrm{Cu}$ associated with oxidisable fraction, up to $100.2 \mathrm{mg} \mathrm{Cu} \mathrm{kg}$, in sediment samples of the profiles below CSO discharges in the Botič stream. $\mathrm{Cu}$ can form organic complexes with organic pollutants discharged from CSOs during rainstorms (Morillo et al., 2002). However, $\mathrm{Cu}$ mobility is not so high as the mobility of $\mathrm{Cd}$ and $\mathrm{Zn}$. Oxidisable fraction of $\mathrm{Cu}$, typical in heavily contaminated samples, is thought to be associated with stable high-molecular-weight humic substances that slowly release small amounts of metals (Lors et al., 2004). High portion of $\mathrm{Cu}, \mathrm{Zn}$ and $\mathrm{Cd}$ was also associated with reducible fraction in sediment samples of the profiles below CSO discharges in the Rokytka stream. This is probably related to the higher oxalate extractable $\mathrm{Fe}, \mathrm{Mn}$ and Al content in the Rokytka stream sediments (Tab. 1). Hydrated $\mathrm{Fe}, \mathrm{Al}$ and $\mathrm{Mn}$ oxides may create coat- 

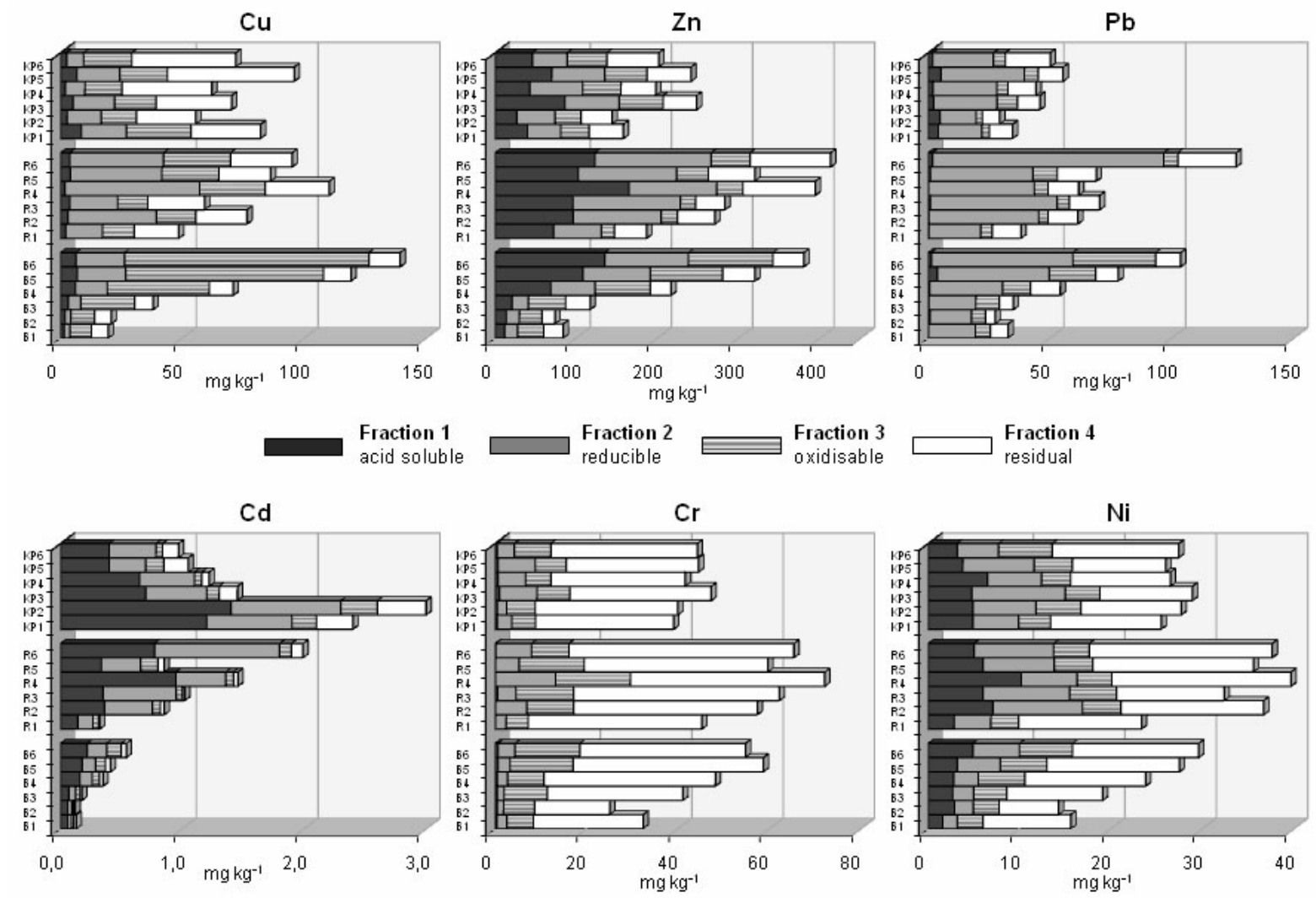

Fig. 5. Chemical speciation of $\mathrm{Cu}, \mathrm{Zn}, \mathrm{Pb}, \mathrm{Cd}, \mathrm{Cr}$ and $\mathrm{Ni}$ in sediments obtained by sequential extraction.

ings on mineral and other particles, and provide other surfaces for metal sorption (Borovec et al., 1993; Ettler et al., 2005).

\section{Conclusion}

A total of 44 urban stream sediment samples in Prague were examined for $\mathrm{Cu}, \mathrm{Zn}, \mathrm{Pb}, \mathrm{Cd}, \mathrm{Cr}$ and $\mathrm{Ni}$. The combined sewer system significantly deteriorates the sediment quality in studied urban streams. High concentrations of $\mathrm{Cu}, \mathrm{Zn}$ and $\mathrm{Pb}$ were found in downstream sampling profiles of the Botič and Rokytka streams due to discharge of CSOs. The multivariate statistics of cluster analysis identified two specific sources of pollution: (i) industrial contamination by $\mathrm{Cd}$ at the Kunratický stream and (ii) CSO impact at the Botič and Rokytka streams. Considerable $\mathrm{Cd}$ contamination of upstream profiles of the Kunratický stream is probably related to the history of plating industry and precious metal processing in that locality.

Speciation data on the basis of sequential extraction indicate that $\mathrm{Cd}$ and $\mathrm{Zn}$ occur in significant quantities in acid soluble fraction (approximately
$50 \%$ of the total $\mathrm{Cd}$ and $30 \%$ of the total $\mathrm{Zn}$ ). Carbonate minerals can be dissolved under acidic conditions, which could induce remobilization of coprecipitated metals. $\mathrm{Pb}$ was mainly found in reducible fraction, $50-70 \%$ of the total $\mathrm{Pb}$ content, and therefore can be potentially released by a change in $\mathrm{Eh} / \mathrm{pH}$ conditions, which could induce the dissolution of $\mathrm{Fe} / \mathrm{Mn}$ (oxi)hydroxides. Low abundances of $\mathrm{Cr}$ in the non-residual fractions indicate its probable natural origin. The observed mobility order of six metals according to calculated mobility factor was $\mathrm{Cd}>\mathrm{Zn}>\mathrm{Ni}>\mathrm{Cu}>\mathrm{Pb}>\mathrm{Cr}$. There was a considerable increase in $\mathrm{Zn}$ mobility, from $15 \%$ to $40 \%$, and an increase of $\mathrm{Cu}$ associated with oxidisable fraction, from $50 \%$ to $70 \%$, in the sediments of the profiles below CSOs at the Botič stream, which receives the discharge of $33 \mathrm{CSOs}$. In terms of environmental significance, $\mathrm{Cd}$ and $\mathrm{Zn}$ can be particularly mobile and bioavailable under acidic conditions, because they are predominantly bound in labile fractions (exchangeable and carbonate). In particular, up to $1.4 \mathrm{mg} \mathrm{Cd} \mathrm{kg}^{-1}$ and $165 \mathrm{mg} \mathrm{Zn} \mathrm{kg}^{-1}$ occur in labile forms in sediments at most contaminated profiles. On the other hand, the remobiliza- 
tion potential and bioavailability of $\mathrm{Cu}$ complexed with organic pollutants discharged from CSOs was found to be lower.

Acknowledgement. The research project has been funded by the Grant Agency AS CR under the project No. IAA200600902 and Institutional Research Plan No. AVOZ20600510. The authors acknowledge the financial assistance on this project.

\section{REFERENCES}

BARNTHOUSE, L.W., DEANGELIS, D.L., GARDNER, R.H., O'NEIL, R.V., SUTER, G.V., VAUGHAN, D.S., 1982: Methodology for Environmental Risk Analysis. ORNL/TM/8167. Oak Ridge National Laboratory. Oak Ridge, TN.

BOROVEC Z., TOLAR V., MRÁZ L., 1993: Distribution of some metals in sediments of the central part of the Labe (Elbe) River: Czech Republic. Ambio, 22, 200-205.

EL SAMRANI A.G., LARTIGES B.S., GHANBAJA J., YVON J., KOHLER A., 2004: Trace element carries in combined sewer dutiny dry and wet weather: an electron microscope investigation. Water Res., 38, 2063-2076.

EL SAMRANI A.G., LARTIGES B.S., VILLIÉRAS F., 2008: Chemical coagulation of combined sewer overflow: Heavy metal removal and treatment optimization. Water Res., 42, 951-960.

ESTÉBE A., MOUCHEL J., THÉVENOT D.R., 1998: Urban runoff impacts on particulate metal concentrations in River Seine. Water Air Soil Pollut., 108, 83-105.

ETTLER V., MIHALJEVIČ M., ŠEBEK O., MOLEK M., GRYGAR T., ZEMAN T., 2005: Geochemical and $\mathrm{Pb}$ isotopic evidence for sources and dispersal of metal contamination in stream sediments from the mining and smelting district of Př́bram, Czech Republic. Environ. Pollut., 142, $27-35$.

EVEN S., MOUCHEL J-M., SERVAIS P., FLIPO N., POULIN M., BLANC S., CHABANEL M., PAFFONI, C., 2007: Modelling the impact of Combined Sewer Overflows on the river Seine water quality. Sci. Total Environ., 375, $140-151$.

FARKAS A., ERRATIO C., VIGANÒ L., 2007: Assessment of the environmental significance of heavy metal pollution in surficial sediment of the River Po. Chemosphere, 68, 761-768

FERGUSSON, J.E., 1990: The Heavy Elements. Chemistry, Environmental Impact and Health Effects. Pergamon Press, Oxford.

FILGUEIRAS, A.V., LAVILLA, I., BENDICHO, C., 2004: Evaluation of distribution, mobility and binding behaviour of heavy metals in surficial sediments of Louro River (Galicia, Spain) using chemometric analysis: a case study. Sci. Total Environ., 330, 115-129.

GOMEZ-ARIZA J.L., GIRALDEZ I., SANCHEZ-RODAS D., MORALES E., 2000: Comparison of the feasibility of three extraction procedures for trace metal partitioning in sediments from south-west Spain. Sci. Total Environ., 246, 271-283.

HILLER E., ŠUTRIEPKA M., 2008: Effect of drying on the sorption and desorption of cooper in bottom sediments from water reservoirs and geochemical partitioning of heavy metals and arsenic. J. Hydrol. Hydromech., 56, 45-58.

HNAŤUKOVÁ P., BENEŠOVÁ L., KOMÍNKOVÁ D., 2009: Impact of urban drainage on metal distribution in sediments of urban streams. Wat. Sci. Tech., 59, 1237-1246.

JAIN, C.K., 2004: Metal fractionation study on bed sediments of River Yamuna, India. Water Res., 38, 569-578.

JONES D.S., SUTER G.W., HULL R.N., 1997: Toxicological Benchmarks for Screening Contaminants of Potential Concern for Effects on Sediment-Associated Biota: 1997 Revision, ES/ER/TM-95/R4, Oak Ridge National Laboratory, Tennessee, USA.

KABALA C., SINGH B.R., 2001: Fractionation and mobility of copper, lead and zinc in soil profiles in the vicinity of a copper smelter. J. Environ. Qual., 30, 485-492.

LEE P-K., YU Y-H., YUN S-T., MAYER B., 2004: Metal contamination and solid phase partitioning of metals in urban roadside sediments. Chemosphere, 60, 672-689.

LORS C., TIFFREAU C., LABOUDIGUE A., 2004: Effects of bacterial activities on the release of heavy metals from contaminated dredged sediments. Chemosphere, 56, 619-630.

MEYBECK M., LESTEL L., BONTÉ P., MOILLERON R., COLIN J.L., ROUSSELOT O., HERVÉ D., DE PONTEVÈS C., GROSBOIS C., THÉVENOT D.R., 2007: Historical perspective of heavy metals contamination $(\mathrm{Cd}, \mathrm{Cr}$, $\mathrm{Cu}, \mathrm{Hg}, \mathrm{Pb}, \mathrm{Zn}$ ) in the Seine River basin (France) following a DPSIR approach (1950-2005). Sci. Total Environ., 375, 204-231.

MORILLO J., USERO J., GRACIA I., 2002: Partitioning of metals in sediments from the Odiel River (Spain). Environ. Int., 28, 263-271.

NÁBĚLKOVÁ J., KOMÍNKOVÁ D., ŠŤASTNÁ, G., 2004: Assessment of ecological status in small urban streams of Prague agglomeration. Wat. Sci. Tech., 50, 285-291.

RAURET G., LÓPEZ-SÁNCHEZ J.F., SAHUQUILLO A., RUBIO R., DAVIDSON C.M., URE A.M., QUEVAUVILLER P., 1999: Improvement of the BCR three-step sequential extraction procedure prior to the certification of new sediment reference materials. J. Environ. Monit., 1, 57-61.

REVITT D.M., MORRISON G.M.P., 1987: Metal speciation variations within separate stormwater systems. Environ. Tech. Lett., 8, 361-372.

SAHUQUILLO A., RIGOL A., RAURET G., 2003: Overview of the use of leaching/extraction tests for risk assessment of trace metals in contaminated soils and sediments. Trends Anal. Chem., 22, 152-158.

SÁŇKA V., 1991: Geochemical map of surface water of Czech Republic 1:50 000. (In Czech.). Sheet 12-42, Zbraslav. Czech Geological Survey, Prague.

STEAD-DEXTER K., WARD N.I., 2004: Mobility of heavy metals within freshwater sediments affected by motorway stormwater. Sci. Total Environ., 334-335, 271-277.

URE A.M., QUEVAUVILLER P., MUNTAU H., GRIEPINK B., 1993: Speciation of heavy metals in soils and sediments. Anaccount of the improvement and harmonization of extraction techniques undertaken under the auspices of the BCR of the Commission of the European Communities. Int. J. Environ. Anal. Chem., 51, 135-151.

Received 9 March 2010 Accepted 26 October 2010 